$\begin{array}{r}\text { Volume and Issues Obtainable at Center for Sustainability Research and Consultancy } \\ \text { Journal of Accounting and Finance in Emerging Economies } \\ \text { ISSN: 2519-0318 ISSN (E) 2518-8488 } \\ \text { Volume 3: Issue 2 December 2017 } \\ \text { JSRᄃ } \\ \text { Journal homepage: } \text { www.publishing.globalcsrc.org/jafee } \\ \hline\end{array}$

\title{
Effect of Comparative Study of Payment System between Malaysia and Republic of Tajikistan
}

\author{
${ }^{1}$ Firdavsi Kholiqov ${ }^{1}$ 'Sara Ramzani, ${ }^{3}$ Valliappan Raju \\ ${ }^{1} \mathrm{PhD}$ aspirant, Limkokwing University, Malaysia \\ ${ }^{2}$ Lecturer, Limkokwing University, Malaysia \\ ${ }^{3}$ Senior Lecturer, Limkokwing University, Malaysia
}

\begin{tabular}{l}
\hline ARTICLEDETAILS \\
\hline History \\
Revised format: Nov 2017 \\
Available online: Dec 2017 \\
\hline Keywords \\
E-payment System, \\
Financial Institution, \\
Comparative Study \\
\hline
\end{tabular}

JEL Classification:

L81, J33

\begin{abstract}
Purpose: The worldwide payment system has another alternative called epayment system now. There are a numbers of different aspects on payment system in two mentioned countries. To utilize the arrangement of epayment, we can spare our time, assets and powers throughout our day by day to exercise the daily e-payment method. The larger part of developing nation is utilizing this e-payment system these days, on the grounds that the e-payment will push the economy to drive speedily. Author has used quantitative method data collection, whereby questionnaire will be provided to respondents. The populations for this research study are financial organizations in both of countries. The target markets are 59 organizations and for data analyzing author will use SPSS technique. Today, the structure of payment system is electronic-payment systems. It is believed that the result of this study significantly support e-payment system. Using cash, cheque and other kind of payment methods are very less observed in Malaysia. Author has tried to find what are the comparative aspects of payment system between two countries and what are the benefit of epayment system which used in Malaysia and unused in Tajikistan. This study will help the payment system of Tajikistan to develop and transform to new payment system accordingly. Therefore, this research will deliver as educational subject and training courses to the Republic of Tajikistan.
\end{abstract}

(C) 2017 The authors, under a Creative Commons AttributionNonCommercial 4.0

Corresponding author's email address: firdavsi14@gmail.com

Recommended citation:Kholiqov,F., Ramzani,S., Raju,V. (2017). Effect of Comparative Study of Payment System between Malaysia and Republic of Tajikistan.Journal of Accounting and Finance in Emerging Economies, 3(2) 131-136.DOI:https://doi.org/10.26710/jafee.v3i2.88

\section{Introduction}

The global payment system is developing speedy every day. The international non-cash payment system is a service which makes our life easier and more comfortable to complete our payments for goods and services. To use the non-cash payment system, we will be able to save our times, resources and powers during completing our daily payment activities (Agency \& Union, 2007). The majority of developed countries using E-payment system nowadays, because the non-cash payment system will push the economy of country drive faster. Now, we can point that all payments in the USA, Canada, British and 
some other country occur by non-cash payment system and in Malaysia as well. Researcher would like to study the Malaysia's payment system and of the Republic of Tajikistan's payment system and compare together. Although many people in developing countries rely on cash as a medium of payments, payment systems policy makers should still endeavor to design and implement strategies that promote the use of non-cash payment instruments not only in urban areas but also in rural areas. The banking community and the general public stands to benefit from electronic based payment schemes in the retail sector (Banda \& Mdwazika, 2006).

\section{Payment system}

Since the purpose of the incentive system is to improve the productivity, the key focus of attention in participative process should be ways to improve productivity. This should be associated with the payment system, able to pay higher rewards when these improvements are achieved. This is not a payment system, which will lead to increased productivity: billing system can only reward increased productivity and make it easier to cooperate with efforts to improve productivity (Thorpe, Bowey, Thorpe, \& Bowey, 2012). A sound and stable macroeconomic and financial system is a prerequisite for increased visibility of the financial markets and the strengthening of institutional capacity for financial systems. The 'payments system' refers to arrangements which allow consumers, businesses and other organizations to transfer funds usually held in an account at a financial institution to one another. It includes the payment instruments - cash, checks and electronic funds transfers which customers use to make payments and the usually unseen arrangements that ensure that funds move from accounts at one financial institution to another (APCA, 2011). Since the first decade of the twenty-first century, many innovations in retail payments have been launched.

This has influenced the way consumers choose to pay and shapes payment processes. Innovations in retail payments not only decrease operating costs and processing times, they also increase social welfare. However, these innovations have raised several issues regarding the stability, robustness, as well as effectiveness of the retail payment systems ("Retail Payment Systems In the OIC Member Countries," 2015).

\subsection{Cash payment system}

The cash payment is the old method of payments system that on the process of payments money will exist. It is also the easy way for buyer to pay to seller. One of the main reasons why money exists is that we need it as a means of payment. After all, the major part of all economic activity in a modern economy requires the buyer to pay the seller. Having inexpensive, simple methods for making payments is important for two reasons. Firstly, lower costs for executing transactions lead to an increased exchange of goods and services in the economy because of the lower cost of buying goods and services. In this way, efficient means of payment serve as a lubricant to the economy. Secondly - and this is an oft-neglected point - payment mediation is an economic activity in itself, which requires real resources. On that basis, efficient means of payment produce direct social benefits that may be substantial (Bergman, Guiborg, \& Segendorf, 2008). There is same researchers analyzes regarding cash payment on the UK, USA, Europe, C\&E Europe and Poland. We can see a bit differences between mentioned countries which the less used cash is USA and UK. Based on Delnevo R. (Bank Machine) figure 1, the challenge of ATM operators. Can cash remain on its throne? A presentation shown at the meeting of ATM operators in Poland help under the auspices of the ATM Industry Association Europe, 10 September 2010 (retail Banking Research data) 
Figure 1: Share of cash in retail payments by countries or regions.

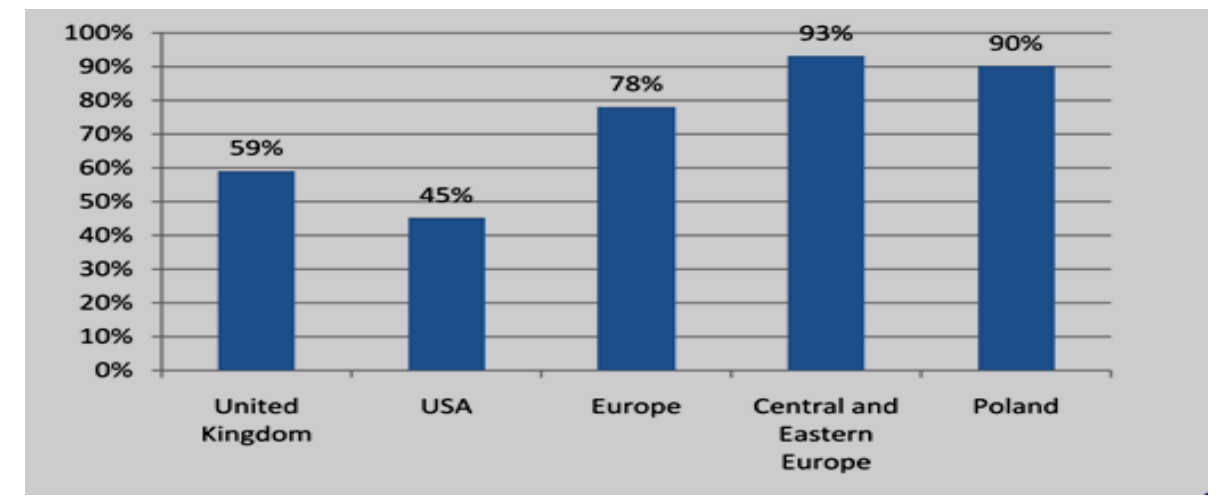

Source:(Górka, 2012).

Nowadays, the sash payment method is not so much popular in the USA and UK because of innovation technology and changing global activities. People prefer use non-cash payment which can be used for online buying goods and services that is more useful and helpful for them. Look to the reference below figure 1.2 UK's research study.

\subsection{E-payment system}

The growth of the technology, in particular the Information and Communications Technology (ICT), had been the most powerful driver for today's economy and commercial activities, including the banking and payment system. Internet banking and e-payment system are not separable because one compliments the other; both systems are critical in establishing the trust mechanism, which is the main foundation required in a successful business and commercial activities (Zulhuda, 2012). The innovation of payment method is non-cash payments, using the cards (credit, debit) during buying goods which money will be not exist. The internet activity use todays very highly recommended, for example buying goods, ordering online become more convenience. This is the easiest way, which we can order online from our homes, offices etc. and we will use non-cash payment system to pay from our cards account, the goods will send to our address. Network externalities have certainly existed in the area of retail payment systems.

However many payment networks display indirect network effects: for example the value of a credit card to its holder depends on the number of merchants that accept it, not on the number of other credit card holders; but since more card holders lead to more accepting merchants, an increase in the number of card holders indirectly affects the network value to an individual card holder. These may include adoption and usage externalities ("Retail Payment Systems In the OIC Member Countries," 2015). The below figure 1.3 is shows how the non-cash payment system (Billion) is significantly increasing every year around the world. The reference uses as resource Capgemini Financial Services Analysis, 2015; ECB Statistical Data Warehouse,2013 figures September 2014; Bank for International Settlements Red Book, 2013 figures released December 2014; Country’s Central Bank annual Report, 2013. 
Figure 2, the transections of non-cash payment from 2009 to 2013 around the world.

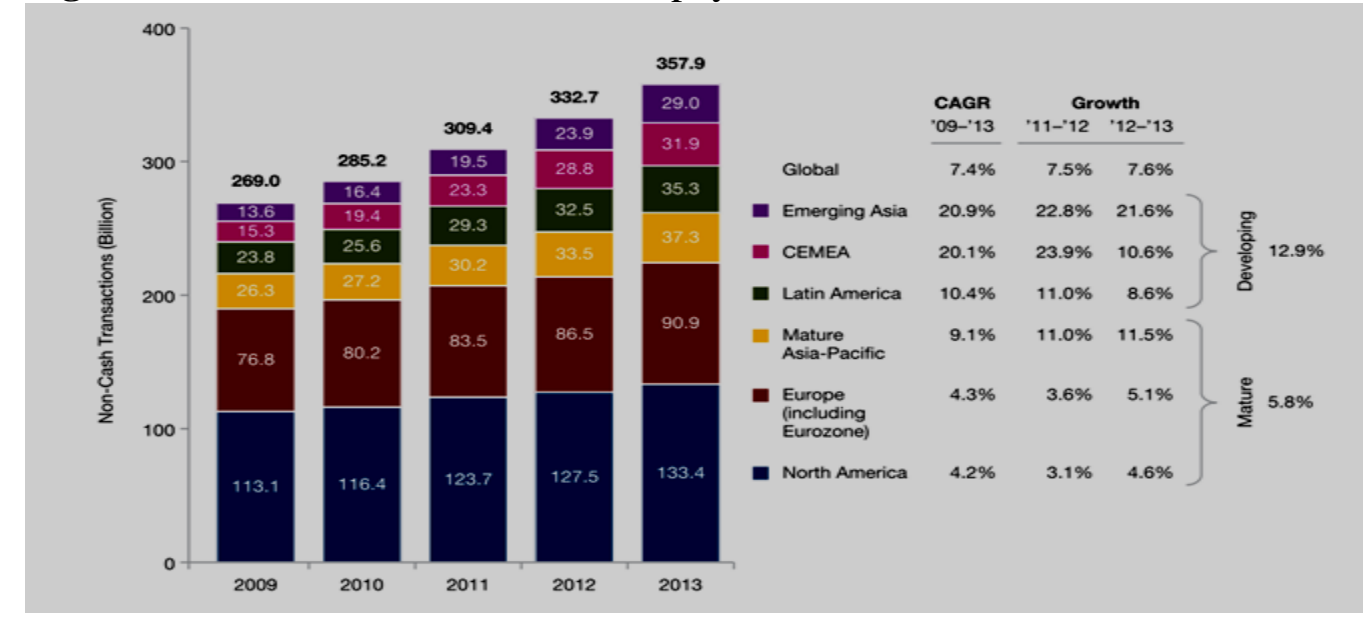

Source:(Tobergte \& Curtis, 2013)

Note: Refer to the Methodology section for detail on countries included in each region; Chart numbers and quoted percentages may not add up due to rounding; some numbers may differ from data published in WPR 2014 due to previous year data updated at the source, figure 2.

\section{Malaysian payment system}

With the exception of cash payments, payments between individuals and organizations are settled at some time through the banking system. Here we explain the payment systems in Malaysia which making payments through the banking system and the various instruments for making payments. Nowadays the payment system turned to electronic payment systems In Malaysia. Using the cash, check or other type of payment is very lass observed. The use of electronic payment systems is increasing, and there will be a decline in the use of cash and check (CBN, 2014). Another notable achievement in the country's payment system infrastructure is in the migration from magnetic stripe payment cards to chip payment cards, where Malaysia was the first country in the Asia Pacific region to do so (Central, 2013). All businesses and individuals in Malaysia need a system for the transfer of money, so that they can pay for goods and services, as well as transfer money to other people. The payment system has been defined by the Bank for International Settlements as follow: "The payment system consists of instruments, banking procedures and, typically, interbank funds transfer systems that ensure and facilitate the circulation of money In fact, it makes it easier to corporations, businesses and consumers to transfer money to each other (CBN, 2014).

Another popular payment system in Malaysia is issuing check payment. It is something a new system check that called electronic processing check. It is easiest way to make transection as well. Bank Negara's effort in improving the payment infrastructure has been continuous. A significant milestone was achieved in 2009 when the e-SPICK system, an image-based check clearing system was introduced. This modernized check processing in Malaysia. In essence, e-SPICK is a check truncation system which converted paper-based processing to electronic processing of checks. Physical checks are no longer sent to the issuing bank and the check clearing center for processing. Instead, images of checks are sent electronically (Central, 2013)

\section{Payment system in Tajikistan}

Development of cards payment system market of the Republic of Tajikistan is one of the important factors in solution of problems on reduction of cash settlements and development of clearing settlements in field of retail payments. For task solution the National Bank of Tajikistan implements measures for improvement of the payment system structure. The project of construction of the Processing Center of the National Payment System card "KortiMilli"(National Card) realized (National Bank of Tajikistan, 2014). 
At present 12 of these credit organizations became participants of the National Payment System card "KortiMilli" (National Card). The number of issued payments card by credit institutions has made 761.3 thousand units that is more for $41,2 \%$ in comparison with last year. From this quantity of issued payment cards $41,8 \%$ are cards of National Payment System known as "KortiMilli", 36,9\% are cards of the International payment systems (Visa and MasterCard), 21,2\% are payment cards of local systems of the credit organizations and $0,01 \%$ are the combined payment cards (UnionPay-NPS “KortiMilli"), see figure 3.

Figure 3, Issuance structure of payment cards from 2013 to 2014 in Tajikistan.

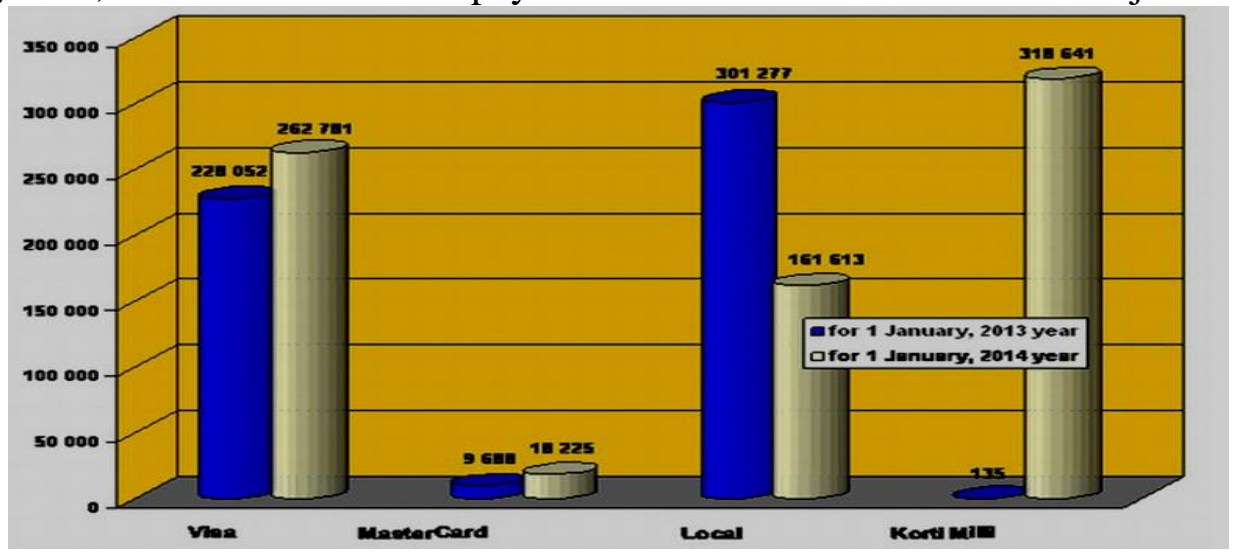

Source: (National Bank of Tajikistan, 2014)

The principle members of payments cards issuing in circulation make the cards issuing in SSB of the Republic of Tajikistan "Amonatbank". The total correlation of payments cards issuing in circulation are 47 per cent, see figure 4 .

Figure 4, the percentages of cards issued by banks and credit organizations in Tajikistan.

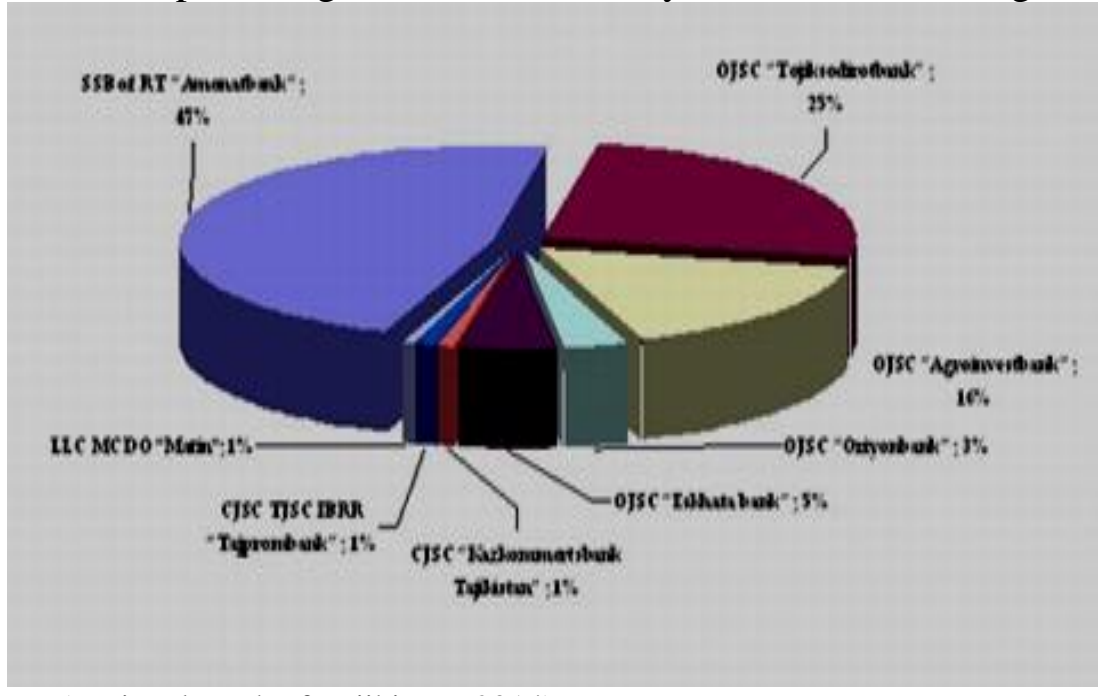

Source:(National Bank of Tajikistan, 2014)

There are number of transactions per thousand unit and volume of operations by millions between cash and non-cash payment in Tajikistan. Infrastructure was developed dynamically on acquiring of payment card. On January 1, 2014 the number of facilities (electronic terminals) used by payment for goods and services as against 2013, increased by 29.4 per cent and has made 343 units, see Figure 5. 
Figure 5, Numbers and volume of payment operation for 2013 and 2014.

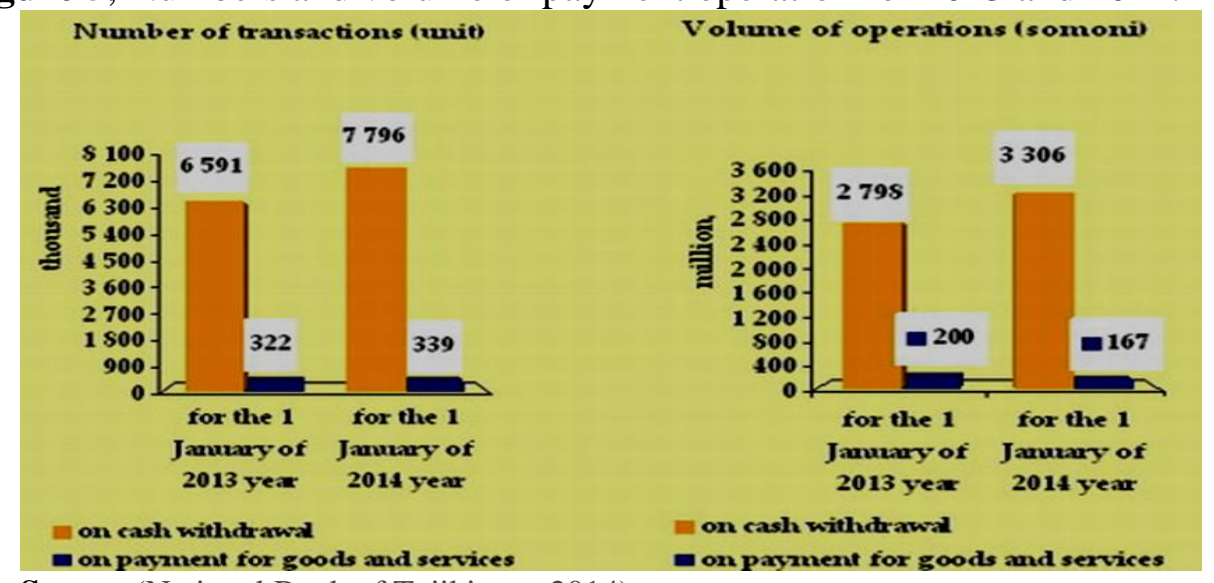

Source:(National Bank of Tajikistan, 2014)

By giving above information regarding the situation and information of payment system of the Republic of Tajikistan, author explaining that the system of payment is sick and doesn't work well, it needs develop and transfer to E-payment system. Population of the Republic of Tajikistan missing opportunity of Epayment system. The author wished that one day it will be available for the country.

\section{References}

Agency, P., \& Union, E. (2007). Krzysztof Rybi ń ski: SEPA and the payment system in Poland, (March), 1-3.

APCA. (2011). The role of cheques in an evolving system, 27.

Banda, L. N., \& Mdwazika, F. (2006). Cash and Retail Payment Systems in Developing Countries, Opportunities and Challenges:The Case of Malawi, 1-5. Retrieved from https://www.sadcbankers.org/subcommittees/PaySystem/media/Documents/Newsletters/Vulindlela_Sep2 008/Malawi_RetailPmnt.pdf

Bergman, M., Guiborg, G., \& Segendorf, B. (2008). Card and cash payments from a social perspective. Sveriges Riksbank Economic Review, (2), 42-59. Retrieved from http://ludwig.lub.lu.se/login?url=http://search.ebscohost.com/login.aspx?direct=true \&db=bth\&AN=33199 $249 \&$ site $=$ eds-live $\&$ scope $=$ site

CBN. (2014). Payments Systems, 51-64. Retrieved from http://www.cenbank.org/Paymentsystem/ Central, B. I. S. (2013). Muhammad bin Ibrahim : Migration to electronic payments, (December), 2-6.

Górka, J. (2012). Payment behaviour in Poland - The benefits and costs of cash, cards and other non-cash payment instruments. The Usage, Costs and Benefits of Cash. Theory and Evidence from Macro and Micro Data. International Cash Conference 2012. 27 - 29 February 2012 Conference Centre of the Deutsche Bundesbank Eltville, Germany, (February), 273-325.

National Bank of Tajikistan. (2014). Payment system of the Republic of Tajikistan (p. 7). Retrieved from www.nbt.tj

Retail Payment Systems In the OIC Member Countries. (2015), (October).

Thorpe, R., Bowey, A., Thorpe, R., \& Bowey, A. (2012). Payment Systems and Performance Improvement. https://doi.org/10.1108/eb055127

Tobergte, D. R., \& Curtis, S. (2013). No Title No Title. Journal of Chemical Information and Modeling, 53(9), 1689-1699. https://doi.org/10.1017/CBO9781107415324.004

Zulhuda, S. (2012). E-payment GatewayServicein Malaysia and the analysis of its legal framework. Australian Journal of Basic and Applied Sciences, 6(11), 233-238. Retrieved from http://www.scopus.com/inward/record.url?eid=2-s2.0-

84871761069\&partnerID=40\&md5=3a4cd5c70e7913b08d8fbbae50bebdb0 